\title{
Mullite-Based Substrates for Polycrystalline Silicon Thin-Film Solar Cells
}

\author{
Masayoshi OHASHI, Yasuo IIDA and Shigetaka WADA* \\ National Industrial Research Institute of Nagoya, 1-1, Hirate-cho, Kita-ku, Nagoya-shi 462-8510 \\ *Toyota Central R \& D Labs., Inc., Nagakute, Aichi 480-1192
}

\author{
薄膜型多結晶シリコンソーラーセル用ムライト基板 \\ 大橋優喜・飯田康夫・和田重孝* \\ 名古屋工業技術研究所, 462-8510 名古屋市北区平手町 1-1 \\ *(株) 豊田中央研究所, 480-1192 愛知県愛知郡長久手町
}

\begin{abstract}
The use of polycrystalline silicon thin-film on inexpensive ceramic substrates for solar cells is one of the most promising approaches to realize both their high performance and cost reduction. Mullite-based ceramics prepared from kaolin-alumina are appropriate for cost-effective substrates for the polycrystalline silicon thin-film solar cells. They fulfill requirements such as thermal and mechanical stability up to $1200^{\circ} \mathrm{C}$ and no thermal expansion mismatch with silicon.

[Received July 12, 1999; Accepted October 7, 1999]
\end{abstract}

Key-words : Mullite, Kaolin, Alumina, Solar cell, Substrate

1. Introduction

Cost reduction for silicon solar cells can be accomplished in reduction of the amount of the expensive silicon and high efficiency in the processing. Polycrystalline silicon thin-film solar cells on inexpensive ceramic substrates are promising candidates for reducing costs. ${ }^{1-4)}$ Preparation from inexpensive raw materials by conventional ceramic processing is one of the requirements for the development of the substrates. Refractoriness and thermal expansion coefficient matched to silicon are also required for the substrates, because high-temperature processing is utilized for high CVD deposition rates and heat treatment for recrystallization of deposited silicon.

Mullite is a crystalline oxide with a low thermal expansion coefficient, but which is a little larger than that of silicon. Mullite-based ceramics were developed using $\mathrm{SiO}_{2}-$ $\mathrm{Al}_{2} \mathrm{O}_{3}$ powders containing $20-40$ mass $\% \mathrm{Al}_{2} \mathrm{O}_{3}$ synthesized by hydrolysis of metal alkoxide as the substrates which silicon chips were mounted on. ${ }^{5)}$ The thermal expansion coefficient of the ceramics at 30 to $400^{\circ} \mathrm{C}$ tended to increase with $\mathrm{Al}_{2} \mathrm{O}_{3}$ content. The optimum property was designed by adjusting $\mathrm{SiO}_{2} / \mathrm{Al}_{2} \mathrm{O}_{3}$ ratio of the starting powders. Mullite ceramics can be also prepared from kaolin and alumina mixtures. ${ }^{6,7)}$ The use of inexpensive kaolin is preferable to more economical processing for the mullite-based substrates. New Zealand kaolin is a suitable candidate, because it is relatively pure compared with the other natural kaolin, and has not a large amount of alkali impurity which is detrimental to the mechanical property of the ceramics at high temperatures and leads to contamination during silicon layer deposition. However, the thermal expansion coefficients at high temperatures $\left(\sim 800^{\circ} \mathrm{C}\right)$ of mullite-based ceramics prepared from the kaolin and alumina has been not yet examined in detail.

In this study, mullite-based ceramics were prepared from New Zealand kaolin with a small amount of low-soda alumina. Compositional dependence of thermal expansion coefficient and flexural strength up to $1300^{\circ} \mathrm{C}$ of the ceramics were examined. The mullite-based ceramics were considered to be the most suitable candidate to serve as a substrate material, because they fulfilled most of the above requirements.

\section{Experimental procedure}

A New Zealand kaolin (Premium, mean grain size : 0.5
Table 1. Chemical Compositions of New Zealand Kaolin and Low-Soda Alumina (in mass\%)

\begin{tabular}{|c|c|c|c|c|c|c|c|c|}
\hline & $\mathrm{SiO}_{2}$ & $\mathrm{Al}_{2} \mathrm{O}_{3}$ & $\mathrm{Fe}_{2} \mathrm{O}_{3}$ & $\mathrm{TiO}_{2}$ & $\mathrm{MgO}$ & $\mathrm{Na}_{2} \mathrm{O}$ & $\mathrm{K}_{2} \mathrm{O}$ & \multicolumn{2}{c}{$\mathrm{O} .1$} \\
\hline $\begin{array}{c}\text { New Zealand Kaolin } \\
\text { (Premium) }\end{array}$ & 48.60 & 36.70 & 0.30 & 0.07 & 0.01 & 0.03 & 0.01 & 13.90 \\
\hline $\begin{array}{c}\text { Low-soda Alumina } \\
\text { (AES-12) }\end{array}$ & 0.06 & 99.9 & 0.01 & - & ---- & 0.04 & - & 0.1 \\
\hline
\end{tabular}

(in mass\%)

$\mu \mathrm{m})$ supplied by Kyoritsu Ceramic Material Co., Japan and low-soda alumina (AES-12, mean grain size : $0.5 \mu \mathrm{m}$ ) from Sumitomo Chemical Co., Ltd., Japan were used. Their chemical compositions are listed in Table 1 . The kaolin consisted of halloysite, cristobalite and quartz identified by Xray diffraction (XRD) analysis.

The kaolin was first dehydrated by heating at $1000^{\circ} \mathrm{C}$ for $2 \mathrm{~h}$. The dehydrated kaolin was mixed with the alumina using vibrational mill in methanol for $48 \mathrm{~h}$. After drying, the mixed powder was passed through a $100 \mu \mathrm{m}$ mesh sieve. The kaolin-alumina mixtures with 45-60 mass $\% \mathrm{Al}_{2} \mathrm{O}_{3}$ were prepared as mentioned above. Powder compacts were formed by cold-isostatic pressing (CIP) at $240 \mathrm{MPa}$, and were sintered at 1550 to $1650^{\circ} \mathrm{C}$ for $2 \mathrm{~h}$. In the firing process, the heating and cooling rate were 5 and $20^{\circ} \mathrm{C} / \mathrm{min}$, respectively. The phases present and the microstructure of sintered bodies were characterized by XRD and scanning electron microscopy (SEM). Bulk density of the sintered bodies was measured by the Archimedes' method using distilled water. Thermal expansion experiments were conducted from 25 to $800^{\circ} \mathrm{C}$ at a heating rate of $10^{\circ} \mathrm{C} / \mathrm{min}$ in air, but for single crystal silicon in Ar. Three-point flexural strength was measured at room temperature to $1300^{\circ} \mathrm{C}$ on bars $3 \times 3 \times 30 \mathrm{~mm}$, ground with a \#400 diamond wheel, and chamfered with a \#600 diamond disk. A span of 20 $\mathrm{mm}$ was used with a crosshead speed of $0.5 \mathrm{~mm} / \mathrm{min}$.

\section{Results and discussion}

Halloysite in the kaolin was dehydrated at $450-550^{\circ} \mathrm{C}$ during heating. Cristobalite and quartz were identified in the kaolin as crystalline phases by XRD after calcination at $1000^{\circ} \mathrm{C}$. Mullite is first detected by XRD in the kaolin heated at $1250^{\circ} \mathrm{C}$. The bodies sintered at 1600 or $1650^{\circ} \mathrm{C}$ were composed of elongated mullite grains and a glass containing impurities as an intergranular phase. On the other 
hand, cristobalite remained in the bodies sintered at $1550^{\circ} \mathrm{C}$ as crystalline phases in addition to mullite. The bodies sintered at $1550^{\circ} \mathrm{C}$ are unsuitable for the substrate of thinfilm polycrystalline silicon solar cell, because large volume change occurred at around $200^{\circ} \mathrm{C}$ in the bodies due to the $\alpha-$ $\beta$ transformation of cristobalite. The surface roughness of the bodies sintered at $1650^{\circ} \mathrm{C}$ was higher than the bodies sintered at $1600^{\circ} \mathrm{C}$. Therefore, the body sintered at $1600^{\circ} \mathrm{C}$ for $2 \mathrm{~h}$ was primarily characterized in this study.

The body sintered at $1600^{\circ} \mathrm{C}$ for $2 \mathrm{~h}$ (NZK16) had a coefficient of thermal expansion (CTE) of $3.48 \times 10^{-6}{ }^{\circ} \mathrm{C}^{-1}$. It was slightly small, compared with that of silicon $(3.8 \times$ $\left.10^{-6}{ }^{\circ} \mathrm{C}^{-1}\right)$. The CTE of single-phase mullite ceramic with 73 mass $\% \mathrm{Al}_{2} \mathrm{O}_{3}$ content sintered at $1600^{\circ} \mathrm{C}$ for $4 \mathrm{~h}$ was measured. The mullite ceramic was prepared from an alkoxide-derived powder with a purity of 99.99\% (Hokko Chemical Industry Co., Ltd.). The CTE of the single-phase mullite ceramic was $5.12 \times 10^{-6}{ }^{\circ} \mathrm{C}^{-1}$, which was more than that of NZK16. Therefore, it is necessary to increase the content of mullite in the sintered body for a good match with the CTE of silicon. The formation of mullite is expected to increase with increasing the addition of alumina as inferred from $\mathrm{SiO}_{2}-\mathrm{Al}_{2} \mathrm{O}_{3}$ phase diagram. ${ }^{8)} \mathrm{A}$ small amount of $\mathrm{Al}_{2} \mathrm{O}_{3}$ was added to the kaolin, and the samples with various $\mathrm{Al}_{2} \mathrm{O}_{3}$ contents were prepared. Figure 1 shows the effect of $\mathrm{Al}_{2} \mathrm{O}_{3}$ content on the CTE of the bodies sintered at $1600^{\circ} \mathrm{C}$ for $2 \mathrm{~h}$. The CTE increased with $\mathrm{Al}_{2} \mathrm{O}_{3}$ content. The increase of mullite content resulted in the increase of the CTE. The CTE of the sintered body with 47 mass $\% \mathrm{Al}_{2} \mathrm{O}_{3}$ (A47) was equivalent to that of silicon.

Figure 2 shows the SEM photographs of the polished surface and the chemical-etched surface of $A 47$ sintered at $1600^{\circ} \mathrm{C}$ for $2 \mathrm{~h}$. A 47 consisted of elongated mullite grains with a size (minor axis) of less than $0.2-0.3 \mu \mathrm{m}$, as shown in Fig. 2(b), and an intergranular glassy phase. Residual pores with a size of $1-2 \mu \mathrm{m}$ existed in the body (Fig. 2(a)). Bulk density and apparent porosity of A47 was $2.73 \mathrm{~g} / \mathrm{cm}^{3}$ and $0.36 \%$, respectively. Figure 3 shows temperature dependence of flexural strength of $\mathrm{A} 47$ sintered at $1600^{\circ} \mathrm{C}$ for $2 \mathrm{~h}$. The strength kept steady up to $1000^{\circ} \mathrm{C}$, and increased to a maximum at $1200^{\circ} \mathrm{C}$, then fell drastically at $1300^{\circ} \mathrm{C}$. This rise was attributed to softening of the intergranular glassy phase at the high temperatures.9) The softening enabled the relaxation of stress concentration by blunting of crack tips. Plastic deformation also occurred at $1200^{\circ} \mathrm{C}$.

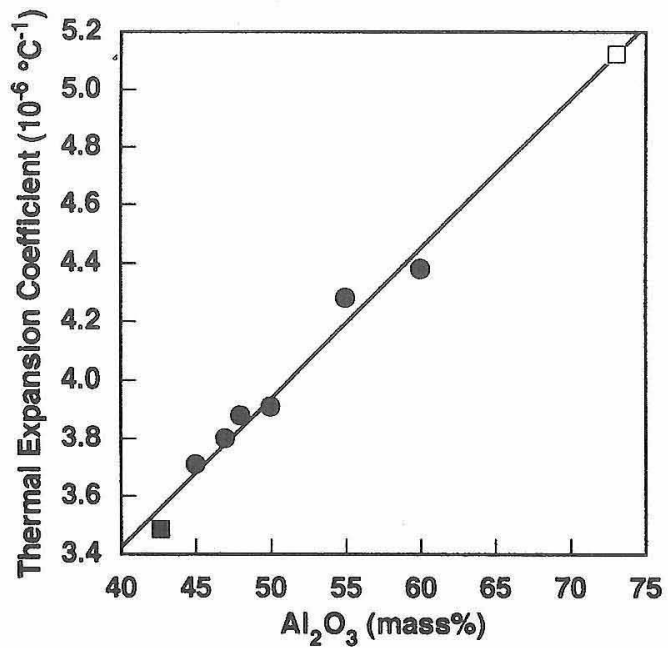

Fig. 1. Thermal expansion coefficients $\left(25-800^{\circ} \mathrm{C}\right)$ of the mullitebased ceramics as a function of $\mathrm{Al}_{2} \mathrm{O}_{3}$ content in the starting mixed powder ( $\square$ the specimen prepared from kaolin alone (NZK16), $\square$ single-phase mullite ceramic).

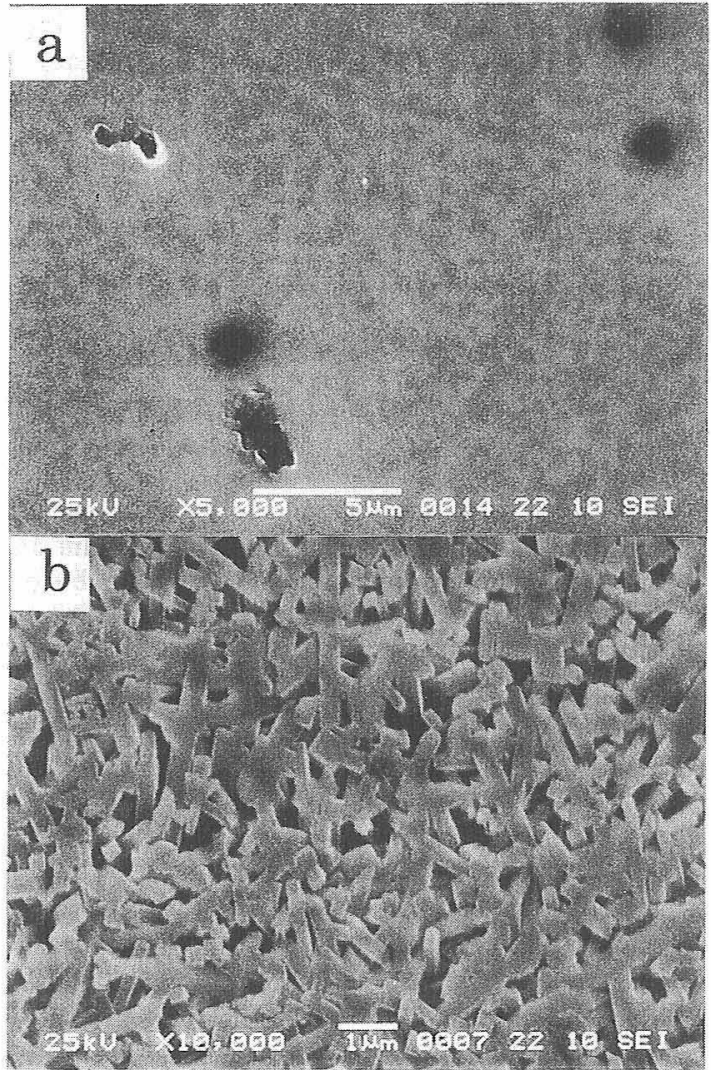

Fig. 2. SEM photographs of the mullite-based ceramic with 47 mass $\% \mathrm{Al}_{2} \mathrm{O}_{3}$ (A47) polished (a) and etched by $1 \% \mathrm{HF}$ solution (b).

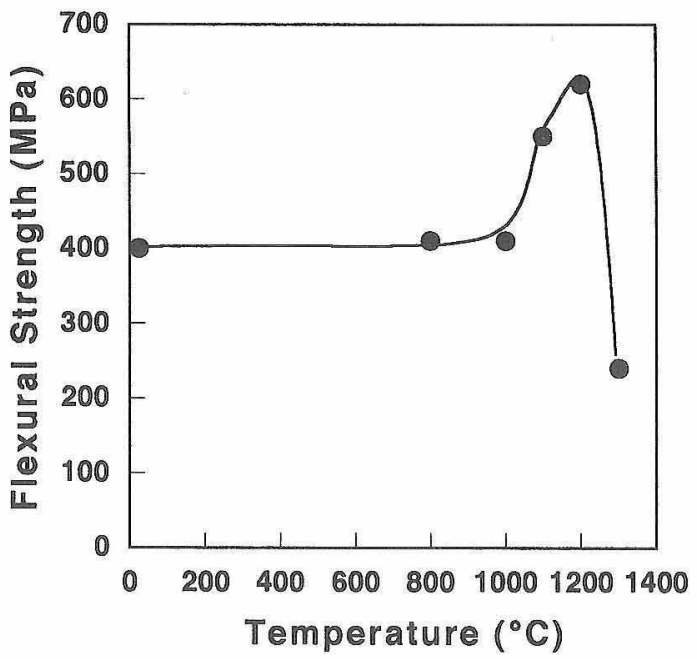

Fig. 3. Temperature dependence of flexural strength of the mullite-based ceramic with 47 mass $\% \mathrm{Al}_{2} \mathrm{O}_{3}$ (A47).

However, the strength remained at the level of more than $400 \mathrm{MPa}$ up to $1200^{\circ} \mathrm{C}$.

\section{Conclusions}

These results prove the mullite-based ceramic (A47) prepared from New Zealand kaolin and low-soda alumina to be refractory enough to be used in the high-temperature process as a substrate for the polycrystalline silicon thin-film solar cells, and to occur no thermal expansion mismatch with silicon layer during heating and cooling. 


\section{References}

1) J. A. M. van Roosmalen, C. J. J. Tool, R. C. Huiberts, R. J. G. Beenen, J. P. P. Huijmans and W. C. Sinke, 25th IEEE Photovoltaic Specialists Conference, Washington, D. C. (1996) pp. 657-60.

2) B. V. Ehrenwall, C. Schmidt, A. Baun, A. Puschel, M. Nell and H. G. Wagemann, 2nd World Conference on Photovoltaic Solar Energy Conversion, Vienna (1998) pp. 1374-77.

3) S. Reber, F, R. Faller, C. Hebling and R. Ludemann, 2nd World Conference on Photovoltaic Solar Energy Conversion, Vienna (1998) pp. 1782-85.

4) A. von Keiz, J. A. M. van Roosmalen, C. J. J. Tool, S. E. A. Schiermeier, A. J. M. M. van Zutphen, F. Fung and G. M.
Christie, 2nd World Conference on Photovoltaic Solar Energy Conversion, Vienna (1998) pp. 1829-32.

5) S. Kanzaki, T. Kurihara, S. Iwai, M. Ohashi and H. Tabata, J. Ceram. Soc. Japan (Yogyo-Kyokai-Shi), 95, 1213-18 (1987).

6) K. Hamano, Z. Nakagawa, G. Cun-Ji and T. Sato, "Mullite," Ed. by S. Sōmiya, Uchidarokakuho (1985) pp. 37-49 [in Japanese].

7) K. C. Liu, G. Thomas, A. Caballero, J. S. Moya and S. D. Aza, Acta Metall. Mater., 42, 489-95 (1994).

8) F. J. Klug, S. Prochazka and R. H. Doremus, J. Am. Ceram. Soc., 70, 750-59 (1987).

9) T. Kawanami, "Mullite," Ed. by S. Sōmiya, Uchidaroukakuho (1985) pp. 123-35 [in Japanese]. 